CONFERENCE PAPER

\title{
GLYCEMIA AS A RELIABLE INDICATOR FOR DIABETES MELLITUS IN DOGS AND CATS
}

\author{
Irena Celeska ${ }^{*}$, Martin Nikolovski², Elena Atanaskova Petrov ${ }^{3}$
}

${ }^{1}$ Faculty of Veterinary Medicine, St. Cyril and Methodius Skopje,

Republic of North Macedonia

${ }^{2}$ Department of Physiology, Faculty of Veterinary Medicine, St. Cyril and Methodius Skopje, Republic of North Macedonia

${ }^{3}$ Department of small animal internal medicine and horses, Faculty of

Veterinary Medicine, St. Cyril and Methodius Skopje, Republic of North Macedonia

\section{*Corresponding author:}

Prof. Dr. Irena Celeska

Department of Pathophisiology, Faculty of Veterinary Medicine-Skopje,

Ss. Cyril and Methodius University Skopje

Address: Lazar Pop-Trajkov 5/7, 1000

Skopje, R. of North Macedonia

Phone: +38970 277999

ORCID: 0000-0001-7488-5911

E-mail: iceleska@fvm.ukim.edu.mk

\begin{abstract}
Diabetes mellitus (DM) is a common endocrinopathy in pet animals with variable pathophysiological metabolic pathways in dogs. Consequently, various hematological and biochemical parameters tend to have high variability. Therefore, the aim of this study was to assess the most reliable and practical hematological and/or biochemical parameter for monitoring DM during the insulin treatment in dogs and cats. This research included 11 pet animals ( 8 dogs and 3 cats) with high resolution of DM clinical symptoms. Red blood cell (RBC) and white blood cell count (WBC) were measured on whole blood samples by using hematological analyzer. Alanine aminotransferase (ALT), alkaline phosphatase (ALKP), glucose, urea, and creatinine were obtained from plasma samples analyzed with automatic colorimetric analyzer. The variability of the parameters was assessed by the coefficient of variation (CV, \%). Parameters with $\mathrm{CV}>34 \%$ were considered with non-normal distribution. $\mathrm{RBC}$ and glucose had $\mathrm{CV}$ of $24 \%$ and $25 \%$, respectively. The other parameters had CV ranging between 39\% and $162 \%$. Polyuria and polydipsia were present in $7 \mathrm{dogs}$ and 1 cat. Polyphagia was present in 4 dogs and 1 cat. Intermittent polyphagia was found in 3 dogs. The clinical manifestations had variable underlying conditions which resulted in variable concomitant organopathies. In conclusion, the blood glucose indicated normal distribution and can be used as a reliable indicator for monitoring DM in diabetic dogs and cats. By using telemetric blood glucose monitoring devices, the veterinary doctors will have continuous and reliable data for the status and the effectiveness of the therapy for their patients.
\end{abstract}

Keywords: Diabetes mellitus, glucose monitoring, insulin, endocrinopathy. 


\section{INTRODUCTION}

The urban trend of living has been affecting the feeding habits, physical activity, and interaction of pet animals with their owners. Despite the close interaction, quite often the owners fail to recognize early clinical signs of some common diseases in their pet animals. Endocrinopathies, which are common in pet animals, may exacerbate if not detected in early stages. The most common pathophysiological mechanism is the divergence of metabolic pathways, which may be the critical point for hormonal disbalance and clinical manifestation of the disease. Different types of diabetes have been identified in pet animals (Hoening, 2002).

Diabetes mellitus (DM) is a common endocrinopathy in pet animals, especially dogs and cats. Diabetic animals are subject to many of the same problems described in human diabetics. Diabetics are more susceptible to infection, and wound healing is often impaired. Decreased insulin promotes lipolysis and moderate hyperlipidemia, which can lead to falsely lowered fructosamine levels, impaired renal circulation, and atherosclerosis (Bennet, 2002). Retinal hypoxia in early diabetic retinopathy before capillary dropout was clinically evident and correlated with endothelial cell death, leukocyte plugging of vessels, and microaneurysms (Linsenmeier at al. 1998).

Home monitoring of the diabetic pet can be challenging for many pet owners. Diabetes, unlike many other diseases, requires everyday treatment from the owner (Mathes, 2002). Complete history, physical examination, laboratory assessment, and client education before discharge are crucial for appropriate patient management and treatment. Numerous factors may contribute to the effectiveness of the treatment (Webb, 2002).
Portable blood glucose monitors (PBGM) are commonly used for measurement and control of the glycemic status in diabetic dogs and cats, and are practical in evaluating the effectiveness of the insulin therapy (Stain and Greco, 2002). Despite the variable readings of the PBGMs (low, normal, and high glucose concentrations), they were reported to be clinically acceptable for monitoring blood glucose concentrations in dogs and cats (Min-Hee Kang at al. 2015).

It was hypothesized that different hematological and biochemical indices have high variability in diabetic dogs and cats compared to blood glucose. Therefore, the aims of this study were to assess the variability level of different hematological and biochemical parameters in diabetic dogs and cats in relation to the clinical manifestation, to identify the one with the lowest variability and highest reliability for detecting and monitoring $\mathrm{DM}$, and to identify the most practical means of its measurement by using telemetric technology in home conditions that can be used by the owners.

\section{MATERIAL AND METHODS}

This study included 11 pet animals (8 dogs and 3 cats) with complete medical records that included anamnestic, clinical, laboratory, and therapeutic data. The common diagnosis for all clinical cases was DM with high resolution of clinical symptoms typical for this endocrinopathy (polyuria, polydipsia, polyphagia, weight loss, and other concomitant organopathies or multisystem diseases). Red blood cell (RBC) and white blood cell counts (WBC) were obtained on whole blood samples, analyzed with Hematology Veterinary Analyzer Exigo (Boule, Sweden). Alanine aminotransferase (ALT), alkaline phosphatase (ALKP), glucose, urea, and creatinine were 
obtained from serum samples analyzed with automatic colorimetric analyzer ChemWell 2910 (Inc, Awareness Technology, USA) according to manufacturer instructions (Human, Germany). Due to the absence of registered canine/feline insulin, different types of human insulin medications were used in a wide range of recommended dose $(0.25 \mathrm{IE} / \mathrm{kg}$ to $1 \mathrm{IE} / \mathrm{kg}$ ) (Apidra, Lantus, Levemir, NovoNordisk, InsulinBasal, Caninsulin) depending on the patients' conditions and therapy response. Daily measurements for blood glucose concentration was obtained with glucometers provided by the owner of pet animal.

Animals' species, breed, age, sex, anamnestic, clinical symptoms, and organopathies data were presented with descriptive statistics. Hematological and biochemical parameters were presented with numerical values and descriptive statistics.

\section{RESULTS}

The pet species, breed, age, and sex included in this study are presented in Table 1. The hematological and biochemical values are presented in Table 2. The anamnestic data, clinical symptoms, and organopathies are presented in Table 3.

The first case was the diabetogenic breed Samoyed Alisa (female) who had hyperglycemia (13 $\mathrm{mmol} / \mathrm{l}$ ), polyuria, polydipsia, and polyphagia. The glucose serum concentration was highly variable and uncontrollable during and after the estrous cycles despite the normal body condition score. The dog had mild anaemia and overloaded hepatic function. There were no other diseases reported in this clinical case.

The second clinical case was Samoyed named Amon. He was admitted in severe clinical condition, stupor, and coma due to metabolic ketoacidosis in the terminal stage of the disease. Anemia (4.19 10-
12/L), severe hyperglycemia (30.33 $\mathrm{mmol} / \mathrm{L})$, and hepatic insufficiency (ALT 327.72 IU/L and ALKP $3346.8 \mathrm{IU} / \mathrm{L}$ ) that extended the hyperglycemia and caused multisystemic dysfunction without detection and treatment of DM.

In the third case (female Samoyed Bona), the owner reported persistent hemorrhagic cystitis. The dog did not respond to the treatment for low urinary infection. Taking in consideration the breed predisposition, the laboratory finding of hyperglycemia (18.2 $\mathrm{mmol} / \mathrm{L})$, the poor maintenance of glycemia, and the clinical history of polyuria and polydipsia, the dog was diagnosed with DM.

In the fourth case, which involved a female French bulldog named Lea, the owner noticed sudden onset of blindness, increased appetite, polyuria, and polydipsia. No other laboratory result and clinical parameter was abnormally altered.

In the sixth case, a similar clinical condition was recorded in an apricot poodle named Lea, who had retinopathy and hepatic impairment (ALT 230.7 $\mathrm{U} / \mathrm{L})$.

In the seventh case, hyperadrenocorticism (ALKP 878.2 U/L) was diagnosed in a Maltese named Fibi by utilizing low-dose dexamethasone suppression test. The lack of treatment of the underlying primary disease was a trigger for developing hyperglycemia (15.6 mmol/L), diabetic nephropathy (urea 23.91 $\mathrm{mmol} / \mathrm{l}$, creatinine $198.11 \mu \mathrm{mol} / \mathrm{L}$ ), and senile dilative cardiomyopathy.

In the eighth case, the puerperal stress had initiated $\mathrm{DM}$ in a Labrador retriever named Aja. The insulin treatment was not effective in controlling the glycemia $(25.5 \mathrm{mmol} / \mathrm{L})$ during the period of parturition and lactation.

In the ninth case, the extended immunosuppressive treatment with prednisolone due to to the positive 
diagnose of stomatogingivitis necroticans in an obese cat named Backer, lead to DM. Oral sulfonylureas treatment was effective for four to six months. Following this, the owner continued with parenteral application of human recombinant analogue of long-acting insulin.
In the tenth case, the detection of DM in a cat named Boobs overlapped with recurrent infection of upper respiratory tract due to immune impairment. The clinical stage requested exogenous insulin supplementation because of the insulin-dependentphase of the disease.

Table 1 Habitus of pet animals

\begin{tabular}{lllll}
\hline No & Pet & breed & Age & Sex \\
\hline 1 & $\operatorname{dog}$ & Samoyed/Alisa & 7 & $\mathrm{~F}$ \\
\hline 2 & $\operatorname{dog}$ & Samoyed/Amon & 6 & $\mathrm{M}$ \\
\hline 3 & $\operatorname{dog}$ & Samoyed/Bona & 6 & $\mathrm{~F}$ \\
\hline 5 & $\operatorname{dog}$ & Samoyed/Dona & & $\mathrm{F}$ \\
\hline 6 & $\operatorname{dog}$ & French Bulldog/Lea & 10 & $\mathrm{~F}$ \\
\hline 7 & $\operatorname{dog}$ & Apricot poodle/Lea & 13 & $\mathrm{~F}$ \\
\hline 8 & Maltese /Fibi & 12 & $\mathrm{~F}$ \\
\hline 9 & cat & Dabrador/Aja & 5 & $\mathrm{~F}$ \\
\hline 10 & cat & Domestic shorthair/Becker & 10 & $\mathrm{M}$ \\
\hline 11 & cat & Domestic shorthair/Ivan & 9 & $\mathrm{M}$ \\
\hline
\end{tabular}

Table 2 Hematological and biochemical results with descriptive statistic analysis

\begin{tabular}{llllllll}
\hline No & $\begin{array}{l}\text { RBC } \\
\left(* 10^{12} / 1\right)\end{array}$ & $\begin{array}{l}\text { WBC } \\
\left(* 10^{9} / 1\right)\end{array}$ & $\begin{array}{l}\text { Glucose } \\
(\mathrm{mmol} / \mathrm{l})\end{array}$ & $\begin{array}{l}\text { ALT } \\
(\mathrm{U} / \mathrm{L})\end{array}$ & $\begin{array}{l}\text { ALKP } \\
(\mathrm{U} / \mathrm{L})\end{array}$ & $\begin{array}{l}\text { Urea } \\
(\mathrm{mmol} / \mathrm{l})\end{array}$ & $\begin{array}{l}\text { Creatinnie } \\
(\mu \mathrm{mol} / \mathrm{L})\end{array}$ \\
\hline 1 & 5.28 & 8.9 & 13.0 & 258 & 202 & 3.1 & 75.6 \\
\hline 3 & 4.19 & 9.4 & 30.33 & 327.72 & 3346.8 & 10.11 & 165.5 \\
\hline 4 & 6.05 & 15.0 & 18.2 & 64.32 & 468.7 & 5.09 & 69.06 \\
\hline 5 & 5.43 & 15.1 & 19.03 & 81.02 & 314.1 & 12.33 & 146.75 \\
\hline 6 & 6.19 & 10.0 & 25.9 & 74.76 & 218.7 & 2.96 & 121.35 \\
\hline 7 & 5.77 & 27.15 & 22.1 & 58.3 & 220.7 & 4.6 & 90.06 \\
\hline 8 & 8.00 & 13.3 & 15.6 & 212.64 & 878.2 & 23.91 & 198.11 \\
\hline 9 & 5.44 & 7.5 & 25.5 & 221 & 243 & 2.4 & 70.0 \\
\hline 10 & 8.11 & 16.7 & 17.36 & 101.45 & 107.08 & 12.65 & 186.20 \\
\hline 11 & 4.38 & 28.3 & 25.4 & 90.47 & 91.0 & 16.69 & 169.39 \\
\hline Mean & 3.98 & 19.8 & 18.11 & 234.17 & 308.6 & 3.33 & 98.45 \\
\hline Standard deviation & 5.71 & 15.56 & 20.96 & 156.71 & 581.72 & 8.83 & 126.41 \\
\hline Coefficient of variation (\%) & 24 & 45 & 25 & 61 & 162 & 79 & 39 \\
\hline
\end{tabular}


Table 3 Anamnestic data, clinical symptoms and organopathies

\begin{tabular}{|c|c|c|c|c|c|c|c|}
\hline No & Polyuria & Polydipsia & Polyphagia & $\begin{array}{l}\text { Weight } \\
\text { loss }\end{array}$ & $\begin{array}{l}\text { Oestral } \\
\text { cycles }\end{array}$ & $\begin{array}{l}\text { Underlying } \\
\text { disease }\end{array}$ & $\begin{array}{l}\text { Organopathies } \\
\text { (Other concomitant } \\
\text { disease) }\end{array}$ \\
\hline 1 & YES & YES & YES & NO & YES & N/A & NO \\
\hline 2 & NO & NO & NO & YES & N/A & N/A & $\begin{array}{l}\text { Polyneuropathy } \\
\text { Coma } \\
\text { Diabetic ketoacidosis }\end{array}$ \\
\hline 3 & YES & YES & Intermittent & $\mathrm{NO}$ & YES & N/A & Hemorrhagic cystitis \\
\hline 4 & YES & YES & Intermittent & YES & YES & & NO \\
\hline 5 & YES & YES & YES & NO & YES & NO & Retinopathy \\
\hline 6 & YES & YES & YES & YES & YES & & Retinopathy \\
\hline 7 & YES & YES & Intermittent & NO & NO & $\begin{array}{l}\text { Hyper } \\
\text { adrenocorticism }\end{array}$ & $\begin{array}{l}\text { Diabetic nephropathy, } \\
\text { cardiomyopathy }\end{array}$ \\
\hline 8 & YES & YES & YES & YES & $\begin{array}{l}\text { After } \\
\text { parturition }\end{array}$ & NO & $\begin{array}{l}\text { Multisystem } \\
\text { insufficiency }\end{array}$ \\
\hline 9 & NO & NO & YES & NO & N/A & $\begin{array}{l}\text { Stomatogingivitis } \\
\text { necroticans }\end{array}$ & Obesity \\
\hline 10 & YES & YES & NO & YES & N/A & $\begin{array}{l}\text { Reccurent } \\
\text { infection }\end{array}$ & Immune impairement \\
\hline 11 & NO & NO & NO & YES & N/A & Hypertiroidisam & $\begin{array}{l}\text { Pulmonary } \\
\text { tromboembolisam } \\
\text { Hypertrophic } \\
\text { cardiomyopathy }\end{array}$ \\
\hline
\end{tabular}

In the eleventh case which involved the cat named Ivan (glycemia $18.11 \mathrm{mmol} / \mathrm{l})$, beside the primary hyperthyroidism, pulmonary thromboembolism, and hypertrophic cardiomyopathy were diagnosed.

\section{DISCUSSION AND CONCLUSION}

$\mathrm{DM}$ is an endocrinopathy in pet animals which occurs due to the lack of insulin (most commonly in dogs), insulin resistance (insulin-independence in cats), estrous cycle (in bitches), extended treatment with immunosuppressive drugs, congenital, and juvenile factors. Pancreatitis and autoimmune processes can affect the function of Langerhans islets, which may lead to DM.
Hyperglycemic and hypoinsulinemic animals have progressive body weight loss despite the increased appetite and food intake due to the inability of the cells to uptake the blood glucose. Unstable diabetic animals have vomiting and diarrhoea that can exacerbate the electrolyte status, which is manifested by osmotic diuresis (Bennett, 2002). Webb in 2002 reviewed the most common causes of DM complications and various strategies for diagnosis and management, applying innovative techniques for control, treatment, and improving animal welfare in pet animals.

All clinical cases described in the current clinical survey demonstrated the difficulties in the maintenance and control of glycemia in diabetic 
dogs and cats in the middle and latter stages of DM.

In all cases, the DM was diagnosed in the middle and/or terminal stages due to the failure of the owners to recognize the early symptoms. The terminal stage is known as diabetic ketoacidosis (DKA) with severe hyperglycemia, acid-base, and electrolyte disbalance. Due to the severity of the metabolic alterations in this phase, it is essential that the treatment should be modified according to each individual case (Heather and Conally, 2002). Continuous and regular monitoring of the animal's condition is a prerequisite for effective maintenance of the glycemic status (Bennett, 2002).

Over the past few decades, PBGMs have been frequently used to monitor blood glucose concentrations in diabetic animals (Min-Hee Kang at al. 2015).

The hematological and biochemical parameters in this study showed high variability. The glycemia and $\mathrm{RBC}$ values (not directly correlated with DM) were normally distributed in all cases. Therefore, it is suggestive that the blood glucose levels can be highly relevant in early detection of DM prior to the development of clinical symptoms. This is especially important in dog and cat breeds which are predisposed to this condition: diabetogenic obese breeds, obese indoor cats, bitches in diestrus, pet animals with concomitant endocrinopathies, and long term immunosuppressive treatment.

The difficulty in blood glucose maintenance with insulin treatment increases the possibility for developing concomitant multisystemic diseases. By preventing the progression of DM in the middle and terminal stages, it is possible to lower the incidence of affecting other systems in the body. This can be achieved by using practical inhome monitoring devices for blood glucose, and by training the owners to recognize early clinical signs, changes in the behaviour, and feeding habits of the pets, and administering medications prescribed by the veterinarians (Mathes, 2002). Telemetric glycemic sensors are modern devices which can be easily used by the owners in home conditions for monitoring blood glucose. By using this kind of technology, the veterinary doctors can get blood glucose readings for their patients in a high detail, which will not necessitate stressful handling of the animals or frequent blood sampling.

In conclusion, various hematological and biochemical parameters tend to be highly variable in diabetic dogs and cats due to the various pathophysiological pathways that this disease can have. The blood glucose indicated normal distribution among the patients included in this study and can be used as a reliable indicator for monitoring DM in diabetic dogs and cats. By using telemetric blood glucose monitoring devices, the veterinary doctors will have continuous and reliable data for the status and the effectiveness of the therapy for their patients.

\section{ACKNOWLEDGEMENTS}

Grateful thanks for collaboration to private veterinary ambulance "Animal Medica", veterinary ambulance "Pet Vet", veterinary ambulance "VetIn".

\section{CONFLICT OF INTEREST}

The authors declared that there is no conflict of interest. 


\section{REFERENCES}

Bennett N. 2002. Monitoring techniques for diabetes mellitus in the dog and the cat. Clin Tech Small Anim Pract, 17(2), 65-69.

Bjornvad CR, Rand JS, Tan HY, Jensen KS, Rose FJ, Armstrong PJ, Whitehead JP. 2014. Obesity and sex influence insulin resistance and total and multimer adiponectin levels in adult neutered domestic shorthair client-owned cats. Domestic Animal Endocrinology, 47, 55-64.

Craig B, Webb. 2002. Troubleshooting the diabetic small animal patient. Clin Tech Small Anim Pract, 17(2), 79-85.

Heather MS, Connally E. 2002. Critical care monitoring considerations for the diabetic patient. Clin Tech Small Anim Pract, 17(2), 73-8.
Hoenig M. 2002. Comparative aspects of diabetes mellitus in dogs and cats. Molecular and Cellular Endocrinology, 197(12), 221-229.

Linsenmeier RA, Braun RD, McRipley MA, Padnick LB, Ahmed J, Hatchell DL, et al. 1998. Retinal hypoxia in longterm diabetic cats. Invest Ophthalmol Vis Sci, 39(9), 1647-57.

Mathes MA. 2002. Home monitoring of the diabetic pet. Clin Tech Small Anim Pract, 17(2), 86-95.

Min-Hee Kang, Do-Hyung Kim, In-SeongJeong, Gab-Chol Choi, Hee-Myung Park. 2015. Evaluation of four portable blood glucose meters in diabetic and non-diabetic dogs and cats, Veterinary Quarterly, 36(1), 2-9.

Stein JE, Greco DS. 2002. Portable blood glucose meters as a means of monitoring blood glucose concentrations in dogs and cats with diabetes mellitus. Clin Tech Small Anim Pract, 17(2), 70-2. 


\section{GLIKEMIJA KAO POUZDAN INDIKATOR DIJABETES MELLITUSA KOD PASA I MAČAKA}

\section{SAŽETAK}

Dijabetes melitus (DM) je česta endokrinopatija kod kućnih ljubimaca sa različitim patofiziološkim metaboličkim putovima kod pasa. Većina ih je usko povezana sa deficijencijom inzulina kod pasa i rezistencijom na inzulin kod mačaka. Širom svijeta je visoka prevalenca dijabetesa kod kućnih ljubimaca. Istraživanje je uključilo 11 kućnih ljubimaca (8 pasa i 3 mačke) s izraženim kliničkim simptomima DM. Težina DM na prijemu je uzrokovana nemogućnošću vlasnika da prepozanju rane simptome kod svojih ljubimaca. Vlasnici su obučeni da obavljaju uobičajene postupke pri stabilizaciji DM. Ispravna edukacija vlasnika predstavlja ključni faktor u uspješnom dugotrajnom vođenju i liječenju dijabetičara. Stabilizacijska faza podrazumijeva dnevnu kontrolu glikemije i njeno bilježenje na način da se svaka dva do tri sata ubodom vadi krv iz šapa, ušiju i usana uz korištenje istog glukometra u trajanju od dvije sedmice. Kreiranje glikemijske krivulje je značajno kako bi se prilagodila doza i učestalost inzulinske terapije. Ova procedura je stresna za vlasnike i za pacijente zbog moguće pojave pogreški kao što su nesposobnost vlasnika, uzbuđenje pacijenta, neodgovarajuće rukovanje inzulinom, skladištenje i inaktivacija, pogrešna vrsta inzulina, predoziranje inzulinom (stanje hipoglikemije), subdoziranje inzulinom, brzi metabolizam inzulina, inzulinska antitijela, neodgovarajuće tehnike aplikacije i pogrešan tip šprice. Pravilna stabilizacija i održavanje terapijskog protokola su bili uspješni kod 6 pacijenata (5 pasa i 1 mačke). Pogreške su kod pacijenata rezultirale polivaskularnom multisistemskom bolešću zbog dijabetične nefropatije, dijabetične ketoacidoze, komplikacija očne bolesti i tromboembolijske vaskularne okluzije.

Praćenje kontrole glikemije telemetrijskim sistemom će imati povoljan učinak na dijabetične kućne ljubimce u stabilizacijskoj fazi i kućne ljubimce sa procijenjenim visokim rizikom od dijabetesa. Rano otkrivanje i prevencija prije razvoja kliničke slike imaju ogroman značaj. Kućni ljubimci sa visokim rizikom su: dijabetogene gojazne vrste, gojazne kućne mačke, reproduktivne kuje u diestrusu, kućni ljubimci sa pratećim endokrinopatijama i dugotrajna imunosupresivna terapija.

Ključne riječi: dijabetes melitus, mjerenje glukoze, inzulin, endokrinopatija 